\title{
Reporting Of Value Added Tax For Retail Traders PKP On Sales Using Electronic Systems (E-Commerce)
}

\author{
Dewi Shintawati Kusnadi* , Denny Kurniawan*** \\ * Student of Master of Administration Science, Tax Management, STIAMI Institute \\ ** Student of Master of Administration Science, Tax Management, STIAMI Institute \\ DOI: 10.29322/IJSRP.11.07.2021.p11532 \\ http://dx.doi.org/10.29322/IJSRP.11.07.2021.p11532
}

\begin{abstract}
The global economic growth and the rapid development of information through electronic systems at this time has made digital business growth very developed, where many companies and individual businesses can be more efficient and make business costs much cheaper, but this information technology system requires the readiness of entrepreneurs to be ready for technology and a good banking system to be able to achieve the desired benefits. The prospect of this electronic system (e-commerce) has a large transaction value such as retail sales activities or known as retail which is a trading business activity (sales of goods or services) that is directly distributed to end consumers. Electronic system business (e-Commerce) is currently unavoidable in the treatment of Taxation. For trade transactions through electronic systems (e-commerce) or online originating from application systems, social media, music, sales of films, videos, and games where all income is received, VAT is imposed based on the legal rules of VAT. Tax treatment in trading activities through the electronic system (PMSE) is subject to VAT on the use of intangible taxable goods (BKPTB) or taxable services (JKP) from outside the customs area within the customs area through PMSE which is regulated through PMK 48/2020 concerning the collection of VAT on utilization of intangible taxable goods or taxable services from outside the customs area and within the customs area through PMSE this policy is effective from 1 July 2020
\end{abstract}

Index Terms- Value Added Tax, Retail Traders, PKP, Electronic System (e-commerce)

\section{INTRODUCTION}

$\mathrm{O}$ A. Background

nline shopping behavior has become a habit for many people, especially during the current pandemic. Moreover, Indonesia is the largest e-commerce market in Southeast Asia. According to Wearesocial and Hootsuite data, around $90 \%$ of internet users in Indonesia have shopped online. One of the biggest factors is the rapid growth of the middle class in Indonesia, which is $21 \%$ of the total upper population of 57.3 million people in 2019.

Retail sales business activity or known as retail is a trading business activity (sale of goods or services) that is directly distributed to end consumers. Retailers are intermediaries in the marketing channel system, where retailers get goods from producers and/or wholesalers who then sell them to final consumers. Trading through this electronic system (e-commerce) can be done through the marketplace platform. The criteria for the Taxable Entrepreneurs of Retail Traders, including those carried out through trading through the electronic system, should refer to the substantive criteria in the PKP business activity, the PKP delivering taxable goods or taxable services to the final consumer and including those carried out through trading through the electronic system, is a taxable entrepreneur. retail merchant tax which is not limited to payments in the form of cash and luggage. To ensure fairness in doing business (level of the playing field), taxpayers who operate retail store sites who have been confirmed as Taxable Entrepreneurs (PKP) also should collect Value Added Tax (VAT) from buyers, the same as in conventional trade. The Taxable Entrepreneur (PKP) of the Retail Trader has the right to issue a Tax Invoice where the treatment is following the provisions of the Taxable Entrepreneur of the Retail Trader. The electronic trading transaction model (e-commerce) makes it easier to fulfill tax obligations for business actors in carrying out their obligations and exercising their tax rights according to the transaction model to be used.

\section{B. Problem Formulation}

Can a Taxable Entrepreneur whose doing electronically or a Taxable Entrepreneur of e-commerce is categorized as a Retail Trader's Taxable Entrepreneur?

\section{Theoretical Foundation}

In the VAT Law Article 4 paragraph (1) letters $d$ and e, it is stated that VAT on the use of Intangible Taxable Goods (BKPTB) or Taxable Services (JKP) from outside the customs area and inside the customs area, while according to PMK 40 of 2010 article 6 paragraph (1) parties who are obliged to collect, deposit and report VAT on the use of Intangible Taxable Goods or Taxable Services from outside the customs area are users or consumers residing in Indonesia in this case following the principle of Collection of VAT, the destination principle, which is adopted by Indonesia. With the issuance of PMK 48 of 2020, this is the legal umbrella in affirming the VAT regulations. Through this PMK, entrepreneurs residing abroad are required to collect, deposit, and report VAT on Intangible Taxable Goods (BKPTB) or Taxable Services (JKP) sold to consumers in Indonesia exceeding 600 million/year or Rp. 50 million/month and/or the number of accessors exceeds 12,000/year or 1,000/month. In B2C transactions, the shadow economy is more prone to occur, as evidenced by research from the Institute for Development of Economics and Finance, which states that consumers in the digital 
business are price-rational consumers so they will choose lower prices, such as the imposition of VAT on Netflix products, Indonesian people will choose and switch to pirated film sites when Netflix products are taxed (Utama \& Noviana). Then a shadow economy will appear where the subject of VAT collectors on Trade Through Electronic Systems (PMSE) does not comply. In PMK 48 of 2020, three parties can be appointed as first collectors, namely sellers of goods or services from abroad. The second is the provider of trading through the electronic system (PPMSE) or overseas digital platform provider. Third, namely the organizer of trade through the Domestic system, so from the three parties who are appointed as collectors both overseas and domestically, they are obliged to collect, deposit, and report VAT on their transactions, therefore it requires the government's efforts in supervising the collection of VAT on Trade Through the System. Electronic (PMSE) in carrying out and carrying out obligations in depositing VAT that has been collected from consumers.

\section{PROBLEM ANALYSIS}

Retail Trade Taxable Entrepreneurs are "Taxable entrepreneurs who deliver Taxable Goods and/or Taxable Services to buyers of Taxable Goods and/or Recipients of Taxable Services with characteristics of final consumers, including those carried out through Trading Through Electronic Systems".

Retailers are now defined as business actors who deliver goods and services to final consumers and are not limited to cashand-carry transactions. However, further provisions regarding procedures for collecting, depositing, and reporting VAT by PKP PE through a third party and the appointment of a third party as a VAT collector. Where there are 2 characteristics of end consumers. Namely: First, buyers of goods and/or service recipients consume directly the goods and/or services purchased or received. Second, the buyer of the goods and/or service recipients also do not use or utilize the goods and/or services purchased or received for business activities.

Retail Trader PKP

\section{Taxable Entrepreneurs (PKP) Retail Traders are divided into two, namely:}

- Entrepreneurs who have fulfilled the requirements as PKP are medium or large-level companies that carry out business activities of retail delivery of BKP.

- Entrepreneurs who do not meet the requirements to become PKP but choose to be confirmed as PKP are they can have PKP status so that the entrepreneur will be more flexible in transacting, for example becoming partners with other PKP.

Retail Merchant PKP is a PKP in which the business activity or work carries out the delivery of

\section{Taxable Goods and or Taxable Services by:}

- $\quad$ through a retail point of sale or directly from one end consumer place to another.

- by way of retail sales made directly to end consumers, without being preceded by a written offer, written order, contract, or auction.
- delivery of the Taxable Goods or the sale and purchase transaction is made in cash and the seller or buyer immediately delivers or brings the Taxable Goods he has purchased.

However, the retailer does not sell goods, but sells services, what must be done:

- Through a place of service delivery that is carried out directly, or can go to the place where the final consumer is located.

- Make sales directly to end consumers, without making offers, orders, contracts, or auctions in advance.

- Conducting buying and selling transactions in cash.

\section{Tax Invoice for Taxable Entrepreneurs Retail Traders:}

For administrative convenience, retailer PKP can make a tax invoice for each delivery of Taxable Goods and or Taxable Services without including information regarding the identity of the buyer as well as the name and signature of the seller in the event of delivering the taxable goods and taxable services to the buyer and the recipient of the consumer. end

PKP Tax Invoice Retailers can also make tax invoices using which all deliveries made to buyers of Taxable Goods or recipients of the same Taxable Services are within 1 calendar month, the tax invoice must be made no later than the end of the following month where the invoice is must contain the name, address, and Taxpayer Identification Number (NPWP) submitting the taxable goods or taxable services, as well as the identity of the buyer of the taxable goods or taxable services. As for the Identity of the Buyer of Foreign Subjects, it must contain the National Identity Number (NIK) or Passport Number.

\section{A. E-Commerce Transactions}

1) Types of e-Commerce Transactions

There are 4 models of e-commerce transactions, including:

\section{a. Online Marketplace}

The Marketplace is a website or online application that facilitates the buying and selling process from various stores. The concept itself is more or less the same as a traditional market. The owner of the marketplace is not responsible for the goods being sold because their job is to provide a place for sellers who want to sell and help them to meet customers and make transactions more simply and easily.

The transaction itself is regulated by the marketplace. Then after receiving the payment, the seller will send the goods to the buyer. One of the reasons why the marketplace is famous is because of the ease and convenience of use. Many describe it as like a department store.

Parties related to the online marketplace, namely:

- Internet mall is an internet-based shopping site consisting of several internet shops which are managed by the organizer of the online marketplace;

- An internet shop is part of an internet mall offered by online marketplace organizers to online marketplace merchants as a place of business activity.

- The online marketplace operator is the party that runs the internet mall business activity. 
- Online Marketplace Merchant is a party that opens and operates an internet shop to sell goods and/or services at an internet mall internet shop.

- Buyers are parties who purchase goods and/or services from online marketplace merchants at internet shops through internet malls.

\section{b. Classified Ads}

Classified Ads are activities that provide a place or time to post content for goods and or services for advertisers to place their ads through sites provided by classified ads organizers. The content can be in the form of text, graphics, explanatory videos, information, and others.

\section{c. Daily Deals}

Daily Deals is an activity to provide a place of business activity in the form of a Daily Deals website as a place for Daily Deals Merchant to sell goods and/or services to Buyers by using Vouchers as a means of payment.

\section{d. Online Retail}

Online Retail is an activity to sell goods and/or services carried out by Online Retail Operators to Buyers on the Online Retail site.

Thus, based on the explanation above, if the Taxable Entrepreneur reports an invoice as long as the transaction is clear and the transaction is clear, then the PKP e-commerce is considered to have made a simple tax invoice and the receipt issued can also be used or recognized as a Tax invoice.

\section{CONCLUSION}

The criteria for the Retail Trader's Taxable Entrepreneurs including those carried out through trading through the electronic system should refer to the substantive criteria in the PKP business activities. PKP, in which the delivery of taxable goods or taxable services to final consumers, including those carried out through trade through electronic systems, is a taxable entrepreneur who is a retail trader who is not limited to payments in the form of cash and luggage. And for PKP Retailers who are allowed to issue tax invoices that are supported must also accommodate PKPs who carry out retail business activities through internet media (online) where buyers can order goods through social media applications or sites provided and purchases can also use credit cards, transfers between accounts designated by managers and financial service providers. Therefore, the technical rules for issuing tax invoices for online retail stores need to be updated with current developments to ensure legal certainty in doing business. So that online retail store owners will be more obedient in fulfilling their tax obligations.

\section{REFERENCES}

[1] Attachment to the Circular Letter of the Director General of Taxes Number SE-62/PJ/2013 concerning Affirmation of Tax Provisions on E-Commerce Transactions.

[2] Law of the Republic of Indonesia Number 11 of 2008 concerning Information and Electronic Transactions.

[3] Law of the Republic of Indonesia Number 42 of 2009 concerning the Third Amendment to Law Number 8 of 1983 concerning Value Added Tax on Goods and Services and Sales Tax on Luxury Goods.

[4] https://www.pajak.go.id/id/article/toko-ritel-online-obligatory to makefaktur-tajak.

[5] Minister of Finance of the Republic of Indonesia 2020. Regulation of the Minister of Finance of the Republic of Indonesia Number 48/PMK.03/2010 concerning Procedures for Appointing Collectors, Collections and Deposits and Reporting Value Added Tax on the use of Intangible Taxable Goods and/or Taxable Services from Abroad Customs Area within the customs area, Trading Through Electronic Systems.

\section{AUTHORS}

First Author - Dewi Shintawati Kusnadi, Student of Master of Administration Science, Tax Management, STIAMI Institute Second Author - Denny Kurniawan, Student of Master of Administration Science, Tax Management, STIAMI Institute 